\title{
Posttranslational modification of intercellular messenger
}

\section{systems}

\author{
Sho Kakizawa ${ }^{1}$, Hiroyuki Kaiya ${ }^{2}$ and Akiyoshi Takahashi ${ }^{3}$ \\ 1 Department of Biological Chemistry, Graduate School of Pharmaceutical Sciences, Kyoto University, Kyoto, Japan \\ ${ }^{2}$ Department of Biochemistry, National Cerebral and Cardiovascular Center Research Institute, Suita, Japan \\ ${ }^{3}$ School of Marine Biosciences, Kitasato University, Sagamihara, Japan \\ *Correspondence: sho-kaki@pharm.kyoto-u.ac.jp \\ Edited and reviewed by: \\ Cunming Duan, University of Michigan, USA
}

Keywords: posttranslational modification, hormone, gaseous messenger, endocrine system, receptor

While it is estimated that the human genome comprises $\sim 27,000$ genes, the total number of proteins in the human proteome is estimated at over one million. In addition to changes at the transcriptional and mRNA levels, "posttranslational modification of proteins" increases the functional diversity of the proteome. Now, it is increasingly recognized that posttranslational modifications of proteins provide important roles in a wide range of "intercellular signaling pathways," such as endocrine systems. For example, $n$-octanoyl modification at Ser(3) is essential for ghrelininduced bioactivities. Moreover, gaseous messengers, such as nitric oxide and hydrogen sulfide are highly active and affect the functions of target proteins by S-nitrosylation and S-sulfhydration, respectively.

This Research Topic is aimed to assemble a series of review articles and original research papers on structural analysis or functional significance of posttranslational modification of/by intercellular messengers, including hormonal messengers and gaseous messengers, in vertebrates and invertebrates: posttranslational modification of peptide hormones such as proopiomelanocortin $(1,2)$, ghrelin (3-5), and hormonal receptors and effectors (6-8). Review articles on gaseous messengers such as hydrogen sulfide (9) and nitric oxide (10) are also included. The contributing papers illustrate variety and importance of biological events regulated by posttranslational modification of functional molecules, and may become major references for those working in the field of physiology and cell biology.

\section{REFERENCES}

1. Takahashi A, Mizusawa K. Posttranslational modifications of proopiomelanocortin in vertebrates and their biological significance. Front Endocrinol (2013) 4:143. doi:10.3389/fendo.2013.00143

2. Yasuda A, Jones LS, Shigeri Y. The multiplicity of post-translational modifications in pro-opiomelanocortin-derived peptides. Front Endocrinol (2013) 4:186. doi:10.3389/fendo.2013.00186
3. Riley LG. Different forms of ghrelin exhibit distinct biological roles in tilapia. Front Endocrinol (2013) 4:118. doi:10.3389/fendo.2013.00118

4. Nishi Y, Mifune H, Yabuki A, Tajiri Y, Hirata R, Tanaka E, et al. Changes in subcellular distribution of $\mathrm{n}$-octanoyl or $\mathrm{n}$-decanoyl ghrelin in ghrelin-producing cells. Front Endocrinol (2013) 4:84. doi:10.3389/fendo.2013.00084

5. Kaiya H, Andoh T, Ichikawa T, Amiya N, Matsuda K, Kangawa K, et al. Determination of ghrelin structure in the barfin flounder (Verasper moseri) and involvement of ingested fatty acids in ghrelin acylation. Front Endocrinol (2013) 4:117. doi:10.3389/fendo.2013.00117

6. Satake H, Matsubara S, Aoyama M, Kawada T, Sakai T. GPCR heterodimerization in the reproductive system: functional regulation and implication for biodiversity. Front Endocrinol (2013) 4:100. doi:10.3389/fendo.2013.00100

7. Saito Y, Hamamoto A, Kobayashi Y. Regulated control of melanin-concentrating hormone receptor 1 through posttranslational modifications. Front Endocrinol (2013) 4:154. doi:10.3389/fendo.2013.00154

8. Wakayama N, Katow T, Katow H. Characterization and endocytic internalization of Epith-2 cell surface glycoprotein during the epithelial-to-mesenchymal transition in sea urchin embryos. Front Endocrinol (2013) 4:112. doi:10.3389/ fendo.2013.00112

9. Shibuya N, Kimura H. Production of hydrogen sulfide from d-cysteine and its therapeutic potential. Front Endocrinol (2013) 4:87. doi:10.3389/fendo.2013. 00087

10. Kakizawa S. Nitric oxide-induced calcium release: activation of type 1 ryanodine receptor, a calcium release channel, through non-enzymatic post-translational modification by nitric oxide. Front Endocrinol (2013) 4:142. doi:10.3389/fendo. 2013.00142

Received: 19 February 2014; accepted: 19 February 2014; published online: 05 March 2014.

Citation: Kakizawa S, Kaiya $H$ and Takahashi A (2014) Posttranslational modification of intercellular messenger systems. Front. Endocrinol. 5:27. doi: 10.3389/fendo.2014.00027

This article was submitted to Experimental Endocrinology, a section of the journal Frontiers in Endocrinology.

Copyright (c) 2014 Kakizawa, Kaiya and Takahashi. This is an open-access article distributed under the terms of the Creative Commons Attribution License (CC BY). The use, distribution or reproduction in other forums is permitted, provided the original author(s) or licensor are credited and that the original publication in this journal is cited, in accordance with accepted academic practice. No use, distribution or reproduction is permitted which does not comply with these terms. 